\title{
ОПТИМІЗАЦІЯ ПЕРВИННОЇ ПРОФІЛАКТИКИ ГЛАУКОМИ ЯК ВЕКТОР ПОСИЛЕННЯ ПРОФІЛАКТИЧНОГО НАПРЯМКУ В ОФТАЛЬМОЛОГІї
}

\author{
ДУ «Український інститут стратегічних досліджень МОЗ України», м. Київ
}

\begin{abstract}
Мета: аналіз шляхів оптимізації первинної профілактики глаукоми для своєчасного її виявлення та попередження розвитку незворотної втрати зорових функцій серед дорослого населення України.

Матеріали і методи. У дослідженні використано комплекс методів - статистичний, соціологічний, структурнологічного аналізу, контент-аналіз нормативної бази.

Результати. Найбільш впливовими щодо розвитку глаукоми є медико-біологічні чинники. За результатами дослідження на первинному рівні надання медичної допомоги запроваджено доофтальмологічний скринінг на глаукому, що дозволяє лікарю загальної практики - сімейному лікарю сформувати групу ризику щодо цього захворювання для проведення відповідних діагностичних досліджень, освітніх та профілактичних заходів.

Висновки. Первинна профілактики глаукоми має стати пріоритетним напрямком діяльності офтальмологічної служби на первинному рівні надання медичної допомоги.
\end{abstract}

КЛЮЧОВІ СЛОВА: глаукома, фактори ризику, первинна профілактика.

За останні роки в Україні сформувалися тенденції до погіршання офтальмологічного здоров'я населення. Зростає поширеність хвороб ока та придаткового апарату, найбільше медикосоціальне значення серед яких має первинна відкритокутова глаукома. За даними різних дослідників, на Земній кулі реєструється близько 45 млн сліпих, з яких 15\% (майже кожен шостий) втратили свій зір внаслідок глаукоми, яка визнана вагомою причиною виникнення сліпоти або слабобачення, займаючи друге місце після катаракти $[5 ; 6 ; 14 ; 15]$. Поширеність глаукоми збільшується з віком: так, якщо у віці 40-49 років вона зустрічається у 0,1-0,2\% випадків, у віці 60-69 років - 2,8\%, то у віці 80 років і старше у $14,3 \%$ випадків. За даними літератури, у тому числі експертів ВООЗ, загальна кількість хворих на глаукому в світі наближається до 100 млн осіб, і до 2030 р. їх кількість подвоїться [8;9].

Первинна відкритокутова глаукома належить до хронічних невиліковних захворювань. Факт встановлення діагнозу глаукоми визначає довічну диспансеризацію хворого, що дозволяє проводити спостереження за перебігом захворювання та рекомендувати ті чи інші медикаменти та(або) оперативне лікування $[1 ; 4 ; 13]$.

Не дивлячись на постійне удосконалення діагностичних, профілактичних і лікувальних методик та можливостей сучасної офтальмології, частота сліпоти від глаукоми в світі за останні 30 років практично не змінилася і становить 14-15\% від

(C) 3.В. Повч, 2014 загальної кількості всіх сліпих. Щорічно в світі реєструється близько 600000 нових випадків сліпоти від глаукоми. При цьому найчастіше глаукома виявляється у занедбаній стадії із залишками зорових функцій, коли навіть медикаментозний контроль внутрішньоочного тиску $€$ утрудненим, і єдиним шляхом досягнення зниження внутрішньоочного тиску (ВОТ) є оперативний $[3 ; 7 ; 10 ; 16]$.

Кількість пацієнтів, хворих на глаукому, яка була вперше виявлена у занедбаній стадії, зростає з віком. Так, у віковій групі 40-45 років частка занедбаних випадків глаукоми складає 0,1\%, а в групі 45 років і старше - більше 10\% [2;13]. Разом $з$ тим, рівень готовності населення і суспільства до усвідомлення необхідності проведення профілактичних заходів з метою попередження цієї складної офтальмологічної патології $€$ невисоким. Лише половина наших громадян знає, що таке глаукома [11]. Ще менша частка хворих на глаукому отримує адекватне лікування. Усе вищенаведене свідчить про наявність об'єктивних труднощів, пов'язаних з профілактикою, своєчасним виявленням, диспансерним спостереженням та лікуванням хворих на глаукому.

Мета дослідження: аналіз шляхів оптимізації первинної профілактики глаукоми для своєчасного її виявлення та попередження розвитку незворотної втрати зорових функцій серед дорослого населення України.

Матеріали і методи. Для проведення дослідження було використано комплекс методів: контент-аналізу існуючої нормативної бази щодо 
профілактики глаукоми та надання медичної допомоги хворим на глаукому на різних їі етапах; структурно-логічного аналізу - для розробки підходів до оптимізації первинної профілактики глаукоми, для їх застосування в практиці лікаря загальної практики - сімейного лікаря (ЛЗП-СЛ); статистичний - для збору, обробки та комплексного аналізу отриманої під час дослідження інформації; соціологічний - для отримання інформації щодо умов і способу життя, характеристики медико-соціальних факторів виникнення глаукоми.

Результати дослідження та їх обговорення. Для сучасного розуміння умов виникнення глаукоми серед дорослого населення нами проведено вивчення факторів їі ризику - безповоротне вибіркове анонімне письмове опитування за розробленими нами анкетами 820 осіб, з яких основна група склала 402, контрольна група 418 осіб. Аналіз результатів опитування проводився із застосуванням комп'ютерних статистичних пакетів програм Statistica 7.0 та Microsoft Excel. Перевірка на якість формулювання питань у даних картах виконана в ході попереднього пілотного дослідження, яке охопило 50 респондентів. Вивчення впливу факторів ризику на виникнення глаукоми здійснювалося поетапно: були виявлені основні фактори ризику виникнення глаукомного процесу; дана їх кількісна оцінка та сформовані групи факторів ризику, що мають визначальний вплив на розвиток глаукоми з метою їх раннього виявлення та своєчасної діагностики глаукоми на ранніх її стадіях.

В остаточному вигляді спеціально розроблена програма для оцінки результатів опитування містила інформацію за виділеними групами факторів ризику: соціально-економічні, соціальногігієнічні, медико-біологічні та медико-організаційні. Крім перерахованих розділів, які заповнювалися під час опитування респондентами, нами додатково, за допомогою анамнестичного методу, проводилося викопіювання інформації з карт амбулаторного обстеження хворих, даних про термін встановлення діагнозу, наявність спадкового анамнезу, супутніх захворювань.

Серед вивчених нами груп факторів ризику глаукоми визначальною виявилася група медико-біологічних чинників. У результаті проведеного дослідження в основній групі встановлено переважання осіб жіночої статі $(53,7 \pm 1,7 \%)$, ймовірність захворіти на глаукому зростає 3 віком. Для відбору осіб в групу ризику щодо розвитку глаукоми необхідним є уточнення наявності сучасних, досліджених нами, факторів ризику, що мають вірогідний вплив та збільшують шанси виникнення глаукоми серед дорослого населення. До них віднесені: нераціональність харчування $(\mathrm{OR}=2,05 ; \mathrm{p}<0,0001)$, коротка (менше 8 годин) тривалість нічного сну (OR=2,97; p<0,0001), часті захворювання протягом року на ГРВІ (OR=1,8; $\mathrm{p}<0,01)$, обтяжений спадковий анамнез щодо глаукоми (OR=16,95; $p<0,0001)$, наявність в анамнезі гіпертонічної хвороби, дистонії та різних судинних порушень (OR=10,15; $p<0,0001)$, цукрового діабету та інших ендокринних порушень (OR=5,31; $p<0,001)$, міопії $(O R=4,89 ; p<0,001)$ та шкідливих звичок, таких як куріння $(\mathrm{OR}=1,81 ; \mathrm{p}<0,001)$.

Знання факторів ризику глаукоми дозволить лікарю загальної практики -сімейному лікарю на первинному рівні надання медичної допомоги сформувати групу ризику щодо цього захворювання для проведення відповідних діагностичних досліджень, освітніх та профілактичних заходів.

У результаті вивчення чинної нормативної бази та затверджених наказом МОЗ України від 14.05.2013 №372 «Про систему офтальмологічної допомоги населенню України» положень: «Положення про систему офтальмологічної допомоги в Україні»; «Положення про обсяг та порядок проведення долікарського офтальмологічного скринінгу», до яких увійшли надані за результатами проведеного нами дослідження пропозиції щодо оптимізації первинної профілактики глаукоми, в порядок надання такої допомоги були внесені наступні зміни. Так, до складу системи офтальмологічної допомоги населенню на первинному рівні включені у тому числі амбулаторії сімейної медицини та фельдшерсько-акушерські пункти, де запроваджується доофтальмологічний скринінг на глаукому. На первинному рівні основними діючими кадровими ресурсами є ЛЗП-СЛ, які мають сертифікат, пройшли післядипломну підготовку в дворічній інтернатурі або на 6-місячному циклі спеціалізації, та медичні сестри загальної практики. Лікар загальної практики - сімейний лікар має обов'язково зібрати скарги та анамнез (спадковий (генетичний), травматичний анамнез, перенесені запальні процеси та судинні катастрофи в оці, прийом препаратів, що можуть підвищувати ВОТ, наявність супутньої патології), перевірити гостроту зору та виміряти ВОТ. Згідно з вищенаведеним наказом, вимірювання ВОТ проводиться усім пацієнтам, хто вперше звернувся за медичною допомогою у віці 40 років і старше, не рідше одного разу на три роки, а особам з групи ризику щодо глаукоми - $з$ 35річного віку щорічно. Додатково, для формування серед населення потреби в проведенні профілактичних оглядів на глаукому, нами розроблені та розповсюджені пам'ятки для пацієнтів у віці 18 років і старше, у тому числі з групи ризику щодо глаукоми.

Для виконання вищезазначених функцій табелем оснащення амбулаторії загальної практикисімейної медицини передбачено наступне 
офтальмологічне обладнання: апарат Рота повногабаритний з таблицями Сівцева-Головіна, тонометр очний, набір пробних окулярних лінз (малий), оправа пробна універсальна [12]. За неможливості проведення ЛЗП-СЛ вищевказаних методів діагностики (за відсутності обладнання тощо) необхідно скерувати пацієнта до лікаряофтальмолога. Також на первинному рівні за участі ЛЗП-СЛ здійснюється нагляд за пацієнтом, якому було встановлено діагноз глаукоми. Такий нагляд повинен включати періодичні контрольні огляди з перевіркою правильності застосування пацієнтом призначених лікарських препаратів та дотримання рекомендацій офтальмолога. Під час обстеження та спеціального ЛЗП-СЛ має сприяти виконанню пацієнтом усіх рекомендацій лікаря-офтальмолога та інших фахівців.

Виявлене лікарем загальної практики підвищення ВОТ вище норми на тлі застосування призначеного офтальмологом лікування зобов'язує його скерувати пацієнта для повторного огляду до офтальмолога для корекції лікування. У разі виявлення стабільної декомпенсації ВОТ та дестабілізації зорових функцій пацієнт пови- нен бути вчасно скерований до офтальмолога для вирішення подальшої стратегії лікування. Усі пацієнти, яким діагностовано будь-який вид глаукоми (первинна чи вторинна) мають знаходитись під постійним спостереженням ЛЗП-СЛ та лікаряофтальмолога.

\section{Висновки}

Розроблені нами шляхи оптимізації первинної профілактики глаукоми, такі як широке інформування населення у віці 18 років і старше, своєчасне виявлення факторів ризику виникнення глаукоми, етапність їі ранньої діагностики, мають стати пріоритетами первинної профілактики і широко застосовуватися у повсякденній практиці ЛЗП-СЛ, а його координація зусиль в цьому напрямку має бути злагодженою і узгодженою 3 діяльністю лікаря-офтальмолога.

Отримані результати свідчать про доцільність подальшого вивчення факторів ризику формування глаукоми серед дорослого населення різних регіонів України та впровадження, з їх урахуванням, сучасних профілактичних та діагностичних технологій.

\section{Список літератури}

1. Витовская О П. Алгоритм медикаментозного лечения глаукомы. Комбинированные препараты / О. П. Витовская, Г. Д. Жабоедов // Офтальмологический журнал. - 2006. — № 3. - С. 89 - 94.

2. Дубинина Ю. А. Комплексная диагностика и мониторинг первичной открытоугольной глаукомы с использованием компьютерного колориметрического анализа и дуплексной допплерографии / Ю. А. Дубинина, Т. Г. Каменских, И. О. Колбенев // Саратовский науч.-мед. журн. - 2009. - № 3. - С. 363-366.

3. Закономірності стану здоров'я населення України / Н. В. Медведовська, В. В. Лазоришинець, Т. К. Кульчицька, Г. О. Слабкий // Щорічна доповідь про стан здоров'я населення України та санітарно-епідеміологічну ситуацію. 2009 рік. - К., 2010. - С. 34-44.

4. Илларионова А. Р. Диспансерное наблюдение больных глаукомой в условиях поликлиники / А. Р. Илларионова, Н. В. Фридман // Клин. офтальмол. - 2003. - № 3. - С. 134-137.

5. Либман Е. С. Состояние и динамика слепоты и инвалидности вследствии патологии органа зрения в России / Е. С. Либман, О. В. Шахова // VII съезд офтальмологов России, Москва, 21-23 ноября 2009 года : сб. научн. статей. - М., 2009. - Ч. 2. - С. 209-214.

6. Либман Е. С. Эпидемиология инвалидизирующих нарушений зрения / Е. С. Либман // Федоровские чтения : сб. тез. - М., 2007. - С. 392.

7. Малов В. М. О совершенствовании методов противоглаукомной работы / В. М. Малов, М. В. Шевченко, Е. В. Карлова // III Всерос. школа офтальмолога : сб науч. тр. - М., 2004. - С. 97-99.

8. Наукове обґрунтування концепції Національної стратегії боротьби із первинною глаукомою в Україні / В. Ф. Москаленко, С. О. Риков, О. П. Вітовська, Д. В. Варивончик // Лікар. справа. - 2010. - № 1-2. - С. 121-127.

9. Нестеров А. П. Глаукома / А. П. Нестеров. - М. : МИА, 2008. - 357 с.

10. Нестеров А. П. Глаукома: дискуссионные проблемы / А. П. Нестеров // Клин. офтальмол. - 2004. - Т. 5, № 2. C. $49-51$.

11. Опыт диспансеризации больных первичной открытоугольной глаукомой с использованием экспертной системы, оценивающей комплаентность / Т. Г. Каменских, Ю. А. Дубинина, И.В.Щербинина // VIII Всероссийская школа офтальмолога : сб. науч. тр. - М., 2009. - С. 195-198.

12. Про затвердження протоколів надання медичної допомоги за спеціальністю «Офтальмологія» : наказ МОЗ України від 15.03.2007 р. № 117 [Електронний ресурс]. - Режим доступу : http://www.moz.gov.ua. - Назва з екрану.

13. Чеченина Н. Г. Основные источники выявления глаукомы на амбулаторном приеме / Н. Г. Чеченина, И. В. Шапошникова, Е. А. Фролова, О.В.Лемберг // Клин. офтальмол. - 2008. - Т. 9, № 4. - С. 119-121.

14. Action plan for the global strategy for the prevention and control of non-communicable diseases (2008-2013). Geneva : WHO, Regional Office for Europe, 2008. - 42 p.

15. American Academy of Ophthalmology. Primary Open - Angle Glaucoma, Preferred Practice Pattern. 2005 [Electronic resource]. - Access mode : http://www.aao.org/ppp. - Title from screen. 
16. Quigley H. A. The number of people with glaucoma worldwide in 2010 and 2020 / H. A. Quigley, A. T. Broman // Br. J. Ophthalmol. - 2006. - Vol. 90. - P. 262-267.

\title{
ОПТИМИЗАЦИЯ ПЕРВИЧНОЙ ПРОФИЛАКТИКИ ГЛАУКОМЫ КАК ВЕКТОР УСИЛЕНИЯ ПРОФИЛАКТИЧЕСКОГО НАПРАВЛЕНИЯ В ОФТАЛЬМОЛОГИИ
}

\author{
3.В. Повч
}

ГУ «Украинский институт стратегически исследований МЗ Украины», г. Киев

\begin{abstract}
Цель: анализ путей оптимизации первичной профилактики глаукомы для своевременного ее выявления и предупреждения развития бесповоротной потери зрительных функций среди взрослого населения Украины.

Материалы и методы. В исследовании использован комплекс методов - статистический, социологический, структурно-логического анализа, контент-анализ существующей нормативной базы.

Результаты. Наиболее влиятельными относительно развития глаукомы являются медико-биологические факторы. По результатам исследования на первичном уровне оказания медицинской помощи внедрен доофтальмологический скрининг на глаукому, что позволяет врачу общей практики - семейному врачу сформировать группу риска относительно данного заболевания для проведения соответствующих диагностических исследований, образовательных и профилактических мероприятий.

Выводы. Первичная профилактика глаукомы должна стать приоритетным направлением деятельности офтальмологической службы на первичном уровне оказания медицинской помощи.
\end{abstract}

КЛЮЧЕВЫЕ СЛОВА: глаукома, факторы риска, первичная профилактика.

\section{OPTIMIZATION OF PRIMARY PREVENTION OF GLAUCOMA AS THE VECTOR OF STRENGTHENING OF PREVENTIVE DIRECTION IN OPHTHALMOLOGY}

Z.V. Povch

PE "Ukrainian Institute of Strategic Researches MHC of Ukraine", Kyiv

Purpose: analysis the ways of optimization of primary prevention of glaucoma for its timely revealing and prevention of development of irreversible loss of visual function among adult population of Ukraine.

Materials and methods. In study a range of methods - statistical; sociological; structural and logical analysis; content analysis of the standard base have been used.

Results. The most influential in glaucoma development are medical and biological factors. According to study at primary level of health care provision introduced ophthalmologic screening of glaucoma, which allows general practitioner/family doctor generate risk group on this disease for carrying out of appropriate diagnostic researches, education and prevention efforts.

Conclusions. Primary preventive of glaucoma should be a priority line of ophthalmic service activity at primary level of medical care.

KEY WORDS: glaucoma, risk factors, primary prevention.

Рукопис надійшов до редакції 20.10.2014 р.

Відомості про автора:

Повч Зоряна Василівна - завідувач офтальмологічного відділення №6 Центру мікрохіруогії ока (м. Київ); тел. роб.: +38(044) 4086300; пошукач ДУ «Український інститут стратегічних досліджень МОЗ України». 